\title{
Temperature Profiles for Germination of Two Species of Winterfat
}

\author{
MICHAEL L. DETTORI, JOHN F. BALLIETTE, JAMES A. YOUNG, AND RAYMOND A. EVANS
}

\begin{abstract}
Germination of seeds of winterfat [Ceratoides lanata (Pursh) Howell] and Eurasian winterfat [C. latens (J.F. Gnel.) Reveal and Holmgren] was compared at 55 constant and alternating temperatures. The seeds of both species germinated at a wide range of temperatures. Optimum germination (defined as not lower than the maximum and its 0.01 probability confidence interval) occurred most frequently at 0,2 , and $5^{\circ} \mathrm{C}$ cold period temperatures alternating with 15 and $20^{\circ} \mathrm{C}$. Optimum temperature regimes tended to be slightly warmer for seeds of Eurasian winterfat. There were large year-to-year differences in the quality of Eurasian winterfat seeds. Three sources of winterfat purchased from commercial seed dealers had low to very low germinability. Seeds of the Hatch selection of winterfat that we tested had a germination response equal to or better than the commercial sources of winterfat seeds.
\end{abstract}

Winterfat [Ceratoides lanata (Pursh) Howell] is one of the most important browse species on the western ranges of North America (Dayton 1931). This drought resistant, semishrub is found from Saskatchewan and Manitoba to northern Mexico.

During the 19th century, pioneer ranchers in the sagebrush (Artemisia) grasslands of the far western United States gradually became a ware that the shrubs that characterize the landscape were generally not preferred by domestic livestock. Probably many times, independently, ranchers were surprised to discover that winterfat was an exception to this generalization. After the first frost in the autumn cattle were found to relish the herbage of winterfat. Growing in the lower reaches of the sagebrush zone, at the margins of salt desert, winterfat furnished forage for cattle during the winter months (Smith 1900, Colton 1904). Late in the 19 th century the developing range sheep industry intensified pressure on winterfat stands (Stewart et al. 1940). As a consequence of consistent overutilization with winter, spring, and summer grazing, many winterfat stands were depleted or nearly eliminated (Stevens et al. 1977). Many of the depleted winterfat stands were invaded first by Russian thistle [Salsola iberica (Sen and Pau)] and later by halogeton [Halogeton glomeratus (Bieb.) C.A. Mey] (Robertson and Kennedy 1954, Eckert 1954).

The need to be able to reestablish winterfat plants on depleted sites by seeding has long been recognized. This need has led to numerous studies of the ecotypic variability, morphology, physiology, and ecology of winterfat seed production, germination, and seedling establishment (Springfield 1974). The seed of winterfat consists of an embryonic plant coiled around a dry speck of perisperm within a seedcoat. The seed is enclosed in bracts which form the utricle or fruit. The surface of the bracts is covered with long silky hairs. The presence of these bracts influences the mechanical handling characteristics, germination, and storage life of winterfat seeds (Stevens et al. 1977). Winterfat seeds require a period of afterripening for optimum germination (Springfield 1972a). The

\footnotetext{
Authors are former research assistants, University of Nevada, and range scientists, USDA, Agricultural Research Service, 920 Valley Road, Reno, Nev. 89512 . Journal Series No. 582 .

This study is a contribution from the University of Nevada and the USDA, ARS, 920 Valley Road, Reno, Nev. 89512.

The authors wish to thank Dr. J.H. Robertson, Mr. Richard Everett, and Mr. Richard Stevens for furnishing portions of the seeds in this study.

Manuscript received April I, 1983.
}

germination of winterfat seeds is also influenced by seedbed temperatures and moisture stress (Springfield 1968a). Optimum germination occurs at relatively warm incubation temperatures of 25 to $27^{\circ} \mathrm{C}$ and exceeds $90 \%$ germination over a wide range of temperatures $\left(10\right.$ to $27^{\circ} \mathrm{C}$ ) (Springfield 1972b). Workman and West (1967) found that genetic variability exists among populations of winterfat and that optimum temperatures for germination vary according to inherent differences among these populations. In addition, wide differences in germinability of winterfat seeds have been observed for seeds collected from the same site in different years (Springfield 1968b and 1973, Moyer and Lang 1976).

Ceratoides species are widely distributed in the Northern Hemisphere. In the Artemisia steppe plant communities of southeastern Europe and central Asia, Eurasian winterfat [Ceratoides latens (J.F. Gnel.) Reveal and Holmgren] fulfills an ecological role apparently similar to winterfat in western North America (Lavrenko 1962). Eurasian winterfat was introduced to the United States and has become naturalized in Elko County, Nev. (personal communication, J.H. Robertson, University of Nevada).

Various selections of winterfat have been evaluated in terms of their suitability for revegetation of depleted rangeland sites (Reidl et al. 1958). A selection identified as Hatch appears promising as a revegetation material (Stevens et al. 1977). Our purpose was to develop germination profiles in relation to constant and alternating incubation temperatures for commercially available winterfat seeds, seeds of the Hatch winterfat selection, and seeds of Eurasian winterfat.

\section{Materials and Methods}

Seeds of Eurasian winterfat were obtained from an irrigated garden located at Reno, Nev., in 1980 and 1981. Winterfat seeds were obtained as samples from commercial lots of seeds collected in northern Utah. Seeds of the Hatch selection of winterfat were obtained from the nursery of the Forest Service, Intermountain Forest and Range Experiment Station, located in Washoe County, Nev.

Seeds were stored in paper bags in the laboratory from harvest until testing 3 to 6 months later. After storage, but before testing, the seeds were threshed from their hairy bracts and cleaned by using an air screen.

Four replications of 25 seeds each were placed on a single layer of germination paper in petri dishes and kept moist with tap water. Seeds were incubated in dark germinators for 4 weeks and germination counts were made at 1,2 , and 4 weeks. Seeds were considered germinated when the embryo completely uncoiled and the hypocotyl arch was raised.

Germination profiles were developed in relation to constant and alternating temperatures. Constant incubation temperatures were $0,2,5,10,15,20,25,30,35$, and $40^{\circ} \mathrm{C}$. Alternating temperature regimes consisted of 16 hours at each constant temperature from 0 to $35^{\circ} \mathrm{C}$ and 8 hours at each higher constant temperature. For example, $0^{\circ} \mathrm{C}$ alternated with all temperatures from 2 through $40^{\circ} \mathrm{C}$, whereas $35^{\circ} \mathrm{C}$ alternated with $40^{\circ} \mathrm{C}$ only. Fifty-five constant and alternating temperature regimes in all were used in the profiles.

Percent germination in relation to the effects of species and 
Table 1. Comparison of germination parameters from temperature profles for seeds of Eurasian winterfat, winterfat, and the Hatch selection of winterfat. Profile based on incubation of seeds at 55 constant and alternating temperatures for four weeks. ${ }^{1}$

\begin{tabular}{|c|c|c|c|c|c|c|}
\hline \multirow[b]{3}{*}{ Profile characteristics } & \multicolumn{6}{|c|}{ Seed Sources } \\
\hline & \multicolumn{2}{|c|}{ Eurasian winterfat } & \multicolumn{2}{|c|}{ Winterfat } & \multicolumn{2}{|c|}{ Hatch selection of winterfat } \\
\hline & $\begin{array}{r}\text { No } 1 \\
(1980)\end{array}$ & $\begin{array}{r}\text { No } 2 \\
(1981)\end{array}$ & No 1 & No 2 & No 3 & \\
\hline & \multicolumn{6}{|c|}{$-\% \ldots$} \\
\hline Mean germination & $72 a$ & $42 b$ & $23 \mathrm{c}$ & 35bc & $35 \mathrm{bc}$ & $46 b$ \\
\hline Regimes with some germination & 98 & 96 & 91 & 95 & 93 & 95 \\
\hline $\begin{array}{l}\text { Mean of regimes with some } \\
\text { some germination }\end{array}$ & 73 & 44 & 26 & 37 & 16 & 49 \\
\hline $\begin{array}{l}\text { Regimes with optimum } \\
\text { germination }\end{array}$ & 27 & 25 & 24 & 27 & 22 & 25 \\
\hline Mean of optima & 98 & 64 & 38 & 53 & 25 & 73 \\
\hline Maximum germination & 100 & 67 & 40 & 55 & 27 & 76 \\
\hline Coefficient of determination ${ }^{2}$ & 71 & 65 & 52 & 65 & 68 & 62 \\
\hline \multicolumn{7}{|l|}{ Germination percentiles } \\
\hline$<10$ & 4 & 11 & 20 & 13 & 29 & 15 \\
\hline $10-25$ & 4 & 11 & 25 & 15 & 64 & 9 \\
\hline $26-50$ & 13 & 31 & 55 & 47 & 7 & 32 \\
\hline $51-75$ & 24 & 47 & 0 & 25 & 0 & 53 \\
\hline $76-90$ & 20 & 0 & 0 & 0 & 0 & 2 \\
\hline$>90$ & 31 & 0 & 0 & 0 & 0 & 0 \\
\hline Germination index & very high & low & very low & low & very low & sub moderate \\
\hline
\end{tabular}

IMean germinations followed by the same letter are no significantly different $(P=0.01)$ as determined by Duncan's multiple range test.

${ }^{2}$ Coefficient of determination indicates how much of the variation is accounted for by the use of the quadratic response surface.

temperature and their interactions was analyzed statistically by an analysis of variance with arc sine transformation. The effects of constant and alternating temperatures on germination percentages were analyzed by use of a quadratic response surface. The quadratic response surface was composed of a series of regression equations, one for each 16-hour cold-period temperature through the series of 8-hour warm-period temperatures, with calculated values and their confidence limits (Evans et al. 1982).

Germination profile characteristics generated from the response surfaces included: mean germination, mean germination of those regimes producing some germination, mean of regimes supporting optimum germination, and maximum germination. Optimum germination was defined as not lower than the maximum germination and its 0.01 probability confidence interval. For each profile, the percent of temperature regimes having germination in the percentile ranges $<10,10$ to 25,26 to 50,51 to 75,76 to 90 , and $>90 \%$ was enumerated. These percentiles were used to develop germinability indices (Young and Evans 1983). The indices provided a means for comparing seedlot quality based on germination temperature profiles.

The germination profiles were subdivided into moderate, colder, warmer, and widely fluctuating seedbed temperatures (Fig. 1). This breakdown of seedbed temperatures was based on the monitoring of microenvironmental parameters in field seedbeds during the spring germination period (Evans et al. 1970).

\section{Results and Discussion}

\section{Temperature Profiles}

\section{Eurasian Winterfat}

Seeds of Eurasian winterfat appeared to be as variable in their germination (Table 1) as the native winterfat seeds (Springfield $1968 \mathrm{a}$ and b). In 1980, the mean germination for the Eurasian winterfat seeds incubated at 55 constant and alternating temperature regimes was $72 \%$. In 1981 , seeds collected from the same plant population and handled during harvest and threshing in a similar manner averaged only $42 \%$ germination. The only temperature regime that produced no germination in both years was a constant $40^{\circ} \mathrm{C}$ (Table 2). Generally, the temperature regimes that supported some germination, and the number of regimes that supported optimum germination were quite similar for the 2 years. The most striking difference between years in germination of Eurasian winterfat seeds was in maximum germination, as indicated by the comparison of $100 \%$ in 1980 with $67 \%$ in 1981 .

By comparing germination percentiles to generate a single characterization of germinability (Young and Evans 1983) we found the Eurasian winterfat seeds had, overall, very high germinability in 1980 and low germinability in 1981 (Table 1).

\section{Winterfat}

Mean germination of winterfat seeds in relation to the temperature profile was significantly ( $P=0.01)$ lower than that observed for Eurasian winterfat seeds produced in 1980 but with 1981 seeds germination of 2 or 3 sources overlapped with the germination of Eurasian winterfat (Table 1). Winterfat seeds did not germinate at $30 / 40\left(30^{\circ} \mathrm{C}\right)$ for 16 hours and $40^{\circ} \mathrm{C}$ for 8 hours daily), $35 / 40$, and $40^{\circ} \mathrm{C}$ (Table 3 ).

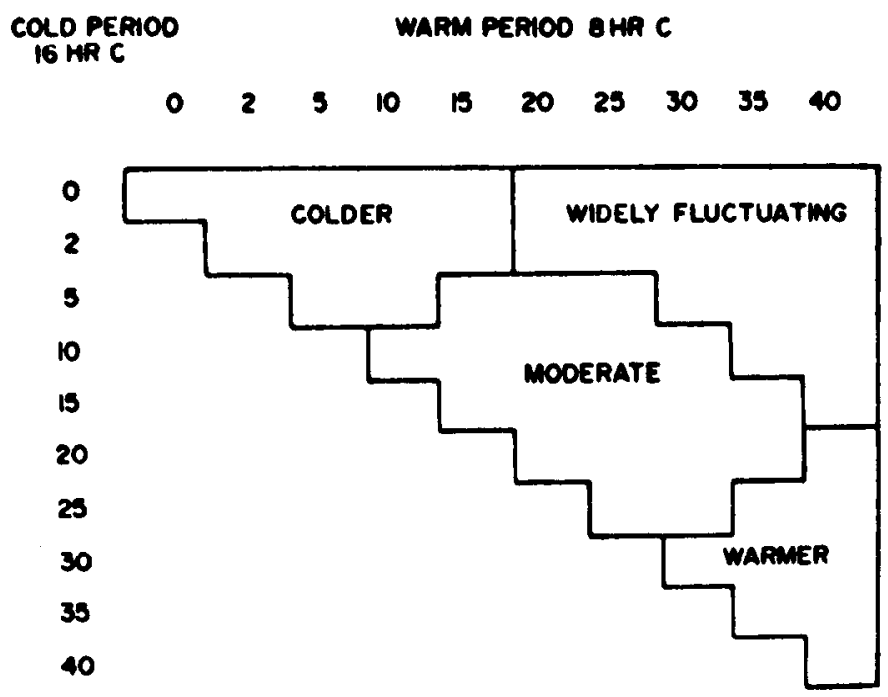

Fig. 1. Temperature profile ranges based on field seedbed monitoring. 
Germinability of the 3 commercial sources of winterfat ranged from low to very low. Apparently, quality of winterfat seeds being marketed is very poor.

\section{Hatch Selection of Winterfat}

The mean germination of seeds of the Hatch selection of winterfat was statistically ( $P=0.01)$ equal to or better than other winterfat seed sources tested and was exceeded only by the 1980 source of Eurasian winterfat seeds (Table 1). Some germination occurred at $95 \%$ of the temperature regimes; only the very warm temperatures did not support germination (Table 4).

Based on the distribution of germination in percentiles, the Hatch seeds were rated as only submoderately germinable (Table 1).

\section{Frequency of Optimum Temperature Regimes}

Temperature regimes that supported optimum germination for Eurasian winterfat, winterfat, and Hatch selections of winterfat seeds occurred over $42 \%$ of the profile (Table 5 ). Only 5 regimes: $0 / 15,2 / 15,2 / 20,5 / 15$, and $5 / 20^{\circ} \mathrm{C}$ always supported optimum germination for all the material tested. Eurasian winterfat and winterfat seeds overlapped in the temperature regimes that supported optimum germination, but the levels of optimum germina- tion were generally higher for seeds of Eurasian winterfat than for seeds of winterfat. Temperatures for optimum winterfat seeds tended to be colder and seldom occurred with $2^{\circ} \mathrm{C}$ warm-period temperatures. In contrast, optimum germination of Eurasian winterfat seed did not occur with 2 or $5^{\circ} \mathrm{C}$ warm-period temperatures and tended to occur at warmer regimes than was observed for winter.

\section{Seedbed Temperatures in Relation to Germination}

Numerically, the seeds of Eurasian winterfat produced in 1980 had the highest mean germination in all classes of seedbed temperatures (Table 6). At moderate and widelyfluctuating seedbed temperatures, the 1980 source of Eurasian winterfat seeds had significantly $(P=0.01)$ higher germination than the other sources. The widely fluctuating temperatures are important for small seeds such as winterfat because the seeds must be planted at shallow depths in the seedbed for best emergence. The only source of seeds that had comparable germination to the 1980 Eurasian winterfat seeds was the Hatch selection of winterfat. Inconsistency in germination of Eurasian winterfat seeds from 1980 to 1981 , however, suggests a potential problem in the use of that species in revegetation.

Results of this study indicate that although germination of win-

Table 2. Estimated percent germination and confidence interval $(P=0.01)$ for seeds of Eurasian winterfat seeds $(1980$, source number 1$)$ incubated at 55 constant and alternating temperatures.'

\begin{tabular}{|c|c|c|c|c|c|c|c|c|c|c|}
\hline \multirow{2}{*}{$\begin{array}{l}\text { 16-Hour } \\
\text { Cold } \\
\text { Period } \\
\left({ }^{\circ} \mathrm{C}\right)\end{array}$} & \multicolumn{10}{|c|}{$\begin{array}{c}\text { 8-Hour warm-period }\left({ }^{\circ} \mathrm{C}\right) \\
\text { Estimated percent germination and confidence interval }\end{array}$} \\
\hline & 0 & 2 & 5 & 10 & 15 & 20 & 25 & 30 & 35 & 40 \\
\hline 0 & $43(11)$ & $54(9)$ & $68(8)$ & $85(7)$ & $96(7)$ & $99(8)$ & $96(7)$ & $85(7)$ & $67(9)$ & $42(12)$ \\
\hline 2 & & $55(9)$ & $69(7)$ & $87(6)$ & $98(6)$ & $100(7)$ & $98(6)$ & $88(6)$ & $70(7)$ & $46(10)$ \\
\hline 5 & & & $70(8)$ & $88(5)$ & $99(5)$ & $100(5)$ & $100(5)$ & $91(5)$ & $73(5)$ & $49(9)$ \\
\hline 10 & & & & $86(8)$ & $98(6)$ & $100(5)$ & $100(5)$ & $92(5)$ & $75(6)$ & $52(8)$ \\
\hline 15 & & & & & $93(9)$ & $98(6)$ & $97(6)$ & $89(6)$ & $73(6)$ & $51(9)$ \\
\hline $\begin{array}{l}20 \\
25 \\
30 \\
35 \\
40\end{array}$ & & & & & & $89(9)$ & $\begin{array}{l}89(6) \\
76(9)\end{array}$ & $\begin{array}{l}81(5) \\
69(6) \\
53(9)\end{array}$ & $\begin{array}{l}66(6) \\
55(6) \\
40(6) \\
20(10)\end{array}$ & $\begin{array}{c}45(9) \\
34(9) \\
20(9) \\
1(10) \\
0(15)\end{array}$ \\
\hline
\end{tabular}

${ }^{1}$ Means underlined are defined as optimum values and are not lower than the maximum and its confidence interval $(p=0.01)$.

Table 3. Estimated percent germination and confidence interval $(P=0.01)$ for seeds of winterfat (Source number 2$)$ incubated at 55 constant and alternating temperatures. 1

\begin{tabular}{|c|c|c|c|c|c|c|c|c|c|c|}
\hline \multirow{2}{*}{$\begin{array}{l}\text { 8-Hour } \\
\text { Cold } \\
\text { Period } \\
\left({ }^{\circ} \mathrm{C}\right)\end{array}$} & \multicolumn{10}{|c|}{$\begin{array}{l}\text { 8-Hour warm-period }\left({ }^{\circ} \mathrm{C}\right) \\
\text { Estimated percent germination and confidence interval }\end{array}$} \\
\hline & 0 & 2 & 5 & 10 & 15 & 20 & 25 & 30 & 35 & 40 \\
\hline 0 & $38(8)$ & $42(7)$ & $47(6)$ & $53(5)$ & $55(6)$ & $53(6)$ & $48(6)$ & $39(6)$ & $27(7)$ & $11(9)$ \\
\hline 2 & & $43(7)$ & $48(5)$ & $53(4)$ & $55(5)$ & $53(5)$ & $48(5)$ & $39(5)$ & $27(5)$ & $11(8)$ \\
\hline 5 & & & $48(6)$ & $53(4)$ & $55(4)$ & $54(4)$ & $48(4)$ & $40(4)$ & $27(4)$ & $11(7)$ \\
\hline 10 & & & & $53(6)$ & $55(4)$ & $53(4)$ & $48(4)$ & $39(4)$ & $27(4)$ & $11(6)$ \\
\hline 15 & & & & & $54(7)$ & $52(5)$ & $46(4)$ & $37(4)$ & $25(5)$ & $9(7)$ \\
\hline 20 & & & & & & $50(7)$ & $44(5)$ & $35(4)$ & $22(5)$ & $6(7)$ \\
\hline $\begin{array}{l}25 \\
30 \\
35 \\
40\end{array}$ & & & & & & & $41(7)$ & $\begin{array}{l}32(4) \\
27(7)\end{array}$ & $\begin{array}{r}19(4) \\
14(5) \\
9(8)\end{array}$ & $\begin{array}{l}3(7) \\
0(7) \\
0(8) \\
0(11)\end{array}$ \\
\hline
\end{tabular}

I Means underlined are defined as optimum values and are not lower than the maximum and its confidence interval $(P=0.01)$. 
Table 4. Estimated percent germination and confidence interval $(P=0.01)$ for seeds the Hatch selection of winterfat seeds incubated at 55 constant and alternating temperatures. ${ }^{1}$

\begin{tabular}{|c|c|c|c|c|c|c|c|c|c|c|}
\hline \multirow{2}{*}{$\begin{array}{l}\text { 8-Hour } \\
\text { Cold } \\
\text { Period } \\
\left({ }^{\circ} \mathrm{C}\right)\end{array}$} & \multicolumn{10}{|c|}{$\begin{array}{c}\text { 8-Hour warm-period }\left({ }^{\circ} \mathrm{C}\right) \\
\text { Estimated percent germination and confidence interval }\end{array}$} \\
\hline & 0 & 2 & 5 & 10 & 15 & 20 & 25 & 30 & 35 & 40 \\
\hline 0 & $48(13)$ & $54(11)$ & $61(9)$ & $69(8)$ & $72(9)$ & $70(9)$ & $62(9)$ & $49(9)$ & $30(10)$ & $6(15)$ \\
\hline 2 & & $55(11)$ & $63(8)$ & $71(7)$ & $74(7)$ & $71(8)$ & $63(7)$ & $50(7)$ & $32(8)$ & $8(12)$ \\
\hline 5 & & & $64(9)$ & $72(6)$ & $75(6)$ & $73(6)$ & $65(6)$ & $52(6)$ & $34(6)$ & $10(10)$ \\
\hline 10 & & & & $73(9)$ & $76(7)$ & $74(6)$ & $66(6)$ & $53(6)$ & $35(7)$ & $11(9)$ \\
\hline 15 & & & & & $74(10)$ & $72(8)$ & $65(7)$ & $52(7)$ & $34(8)$ & $10(10)$ \\
\hline $\begin{array}{l}20 \\
25 \\
30 \\
35 \\
40\end{array}$ & & & & & & $\overline{68(11)}$ & $\begin{array}{l}61(8) \\
55(10)\end{array}$ & $\begin{array}{l}49(6) \\
43(7) \\
35(10)\end{array}$ & $\begin{array}{c}31(8) \\
25(7) \\
17(8) \\
7(12)\end{array}$ & $\begin{array}{l}7(11) \\
2(10) \\
0(10) \\
0(12) \\
0(17)\end{array}$ \\
\hline
\end{tabular}

'Means underlined are defined as optimum values and are not lower than the maximum and its confidence interval $(P=0.01)$.

Table 5. Frequency of optimum temperature regimes for germination of Eurasian winterfat, winterfat, and Hatch selection of winterfat seeds combined.

\begin{tabular}{|c|c|c|c|c|c|c|c|c|c|c|}
\hline \multirow{2}{*}{$\begin{array}{l}8 \text {-Hour } \\
\text { Cold } \\
\text { Period } \\
\left({ }^{\circ} \mathrm{C}\right)\end{array}$} & \multicolumn{10}{|c|}{$\begin{array}{l}\text { 8-Hour warm-period }\left({ }^{\circ} \mathrm{C}\right) \\
\text { Estimated percent germination and confidence interval }\end{array}$} \\
\hline & 0 & 2 & 5 & 10 & 15 & 20 & 25 & 30 & 35 & 40 \\
\hline $\begin{array}{r}0 \\
2 \\
5 \\
10 \\
15 \\
20 \\
25 \\
30 \\
35 \\
40\end{array}$ & & 17 & $\begin{array}{l}17 \\
17\end{array}$ & $\begin{array}{l}83 \\
83 \\
83 \\
50\end{array}$ & $\begin{array}{r}10 \\
100 \\
100 \\
83 \\
50\end{array}$ & $\begin{array}{r}83 \\
100 \\
100 \\
83 \\
83 \\
17\end{array}$ & $\begin{array}{l}17 \\
17 \\
34 \\
50 \\
17\end{array}$ & & & \\
\hline
\end{tabular}

Table 6 Germination of seeds of Eurasian winterfat, winterfat, and the Hatch selection of winterfat in relation to a discriminate breakdown of seedbed temperatures.'

\begin{tabular}{|c|c|c|c|c|c|c|}
\hline \multirow[b]{3}{*}{ Seedbed temperatures ${ }^{2}$} & \multicolumn{6}{|c|}{ Percent germination } \\
\hline & \multicolumn{2}{|c|}{ European winterfat } & \multicolumn{2}{|c|}{ Winterfat } & \multicolumn{2}{|c|}{ Winterfat } \\
\hline & Source 1 & Source 2 & Source 1 & Source 2 & Source 3 & \\
\hline & & & & & & \\
\hline Moderate & $84 a$ & $55 \mathrm{~b}$ & $31 \mathrm{~cd}$ & $45 \mathrm{bc}$ & $17 d$ & $55 b$ \\
\hline Colder than moderate & $74 a$ & $49 \mathrm{bc}$ & $33 \mathrm{~cd}$ & $49 b c$ & $24 d$ & $64 a b$ \\
\hline Widely fluctuating & $68 a$ & $36 \mathrm{~b}$ & $18 \mathrm{c}$ & $27 \mathrm{bc}$ & $13 c$ & $37 \mathrm{~b}$ \\
\hline Warmer than moderate & $31 \mathrm{a}$ & $13 \mathrm{ab}$ & $8 b$ & llab & $5 b$ & $13 \mathrm{ab}$ \\
\hline
\end{tabular}

1Means within rows followed by the same letter are not significantly different at the 0.01 level of probability as determined by Duncan's multiple range test. 2See figure I for temperature regimes in each category.

terfat is low, its germination characteristics in relation to temperature make this plant a likely candiate for successful seeding on sagebrush rangelands because optimum germination occurs at temperatures prevalent in the field during late fall or early spring.

\section{Literature Cited}

Colton, J.S. 1904. A report on range conditions of central Washington. Wash. Agr. Exp. Sta. Bull. 60.
Dayton, W.A. 1931. Important western browse plants. U.S. Dep. Agr. Misc. Pub. 101.

Eckert, R.E., Jr. 1954. A study of competition between whitesage and halogeton in Nevada. J. Range Manage. 7:223-225.

Evans, R.A., H.R.' Holbo, R.E. Eckert, Jr., and J.A. Young. 1970. Functional environment of downy brome communities in relation to weed control and revegetation. Weed Sci. 18:154-162.

Evans, R.A., D.N. Book, D.A. Easi, and J.A. Young. 1982. Quadratic response surface analysis of seed germination data. Weed Sci. 30:411-416. 
Lavrenko, E.M. 1962. Principal features of the botanical geography of deserts of Eurasia and North Africa (in Russian), Nauka, Moscow-Leningrad.

Moyer, J.L., and R.L. Lang. 1976. Variable germination response to temperature for different sources of winterfat seed. J. Range Manage. 29:320-321.

Reidl, W.A., R.L. Lang, and K.H. Assay. 1958. Selection and improvement of Eurotia lanata (winterfat) and other species of salt desert areas. Wyo. Agr. Exp. Sta. Mimeo. Cir.

Robertson, J.H., and P.B. Kennedy. 1954. Half century changes on northern Nevada ranges. J. Range Manage. 7:117-121.

Smith, J.G. 1900. Fodder and forage plants, exclusive of the grasses. U.S. Dep. Agr. Div. Agrosotology. Bull. 2.

Springfield, H.W. 1968a. Germination of winterfat seeds under different stresses and temperatures. J. Range Manage. 21:314-315.

Springfield, H.W. 1968b. Age and year of collection affect germination of winterfat seeds. U.S. Dep. Agr., Forest Service. Rocky Mountain Forest and Range Exp. Sta. Research Note RM-112.

Springfield, H.W. 1972. Winterfat seeds undergo after-ripening. J. Range Manage. 25:479-480.
Springfield, H.W. 1972b. Optimum temperatures for germination of winterfat. J. Range Manage. 25:69-70.

Springfield, H.W. 1973. Large seeds of winterfat germinate better. J. Range Manage. 26:153-154.

Springfield, H.W. 1974. Eurotia lanata (Pursh) Moq. winterfat. p. 398-400. In: Seeds of woody plants in the United States. U.S. Dep. Agr., Forest Service Handbook 450.

Stevens, Richard, B.C. Giunta, K.R. Jorgensen, and A.P. Plummer. 1977. Winterfat. Pub. No. 77-2. Utah State Division of Wildlife Resources.

Stewart, George, W.P. Cottam, and S.S. Hutchings. 1940. Influence of unrestricted grazing on northern salt desert plant associations in western Utah. J. Agr. Res. 60:289-316.

Workman, J.P., and N.E. West. 1967. Germination of Eurotia lanata in relation to temperature and salinity. Ecology 48:659-661.

Young, J.A., and R.A. Evans. 1983. Temperature profiles for germination of cool season range grasses. ARR-W-17. U.S. Dep. Agr., Agr. Res. Ser.-Western Region. 